\title{
Obstetric Nursing in best practices of labor and delivery care
}

\author{
Enfermagem Obstétrica nas boas práticas da assistência ao parto e nascimento \\ Enfermería Obstétrica en las buenas prácticas de la asistencia al parto y el nacimiento
}

Thales Philipe Rodrigues da Silva'

ORCID: 0000-0002-7115-0925

Érica Dumont-Pena'

ORCID: 0000-0003-1220-6041

Ana Maria Magalhães Sousa' ORCID: 0000-0002-7096-592X

Torcata Amorim ORCID: 0000-0002-9177-9958

Luísa Castanheira Tavares' ORCID: 0000-0002-5651-273X

Débora Cabral di Pietra Nascimento' ORCID: 0000-0002-1643-4001

Kleyde Ventura de Souza' ORCID: 0000-0002-0971-1701

Fernanda Penido Matozinhos ORCID: 0000-0003-1368-4248

'Universidade Federal de Minas Gerais. Belo Horizonte, Minas Gerais, Brazil.

How to cite this article: Silva TPR, Dumont-Pena E, Sousa AMM, Amorim T,

Tavares LC, Nascimento DCP, et al. Obstetric Nursing in best practices of labor and delivery care. Rev Bras Enferm. 2019;72(Suppl 3):235-42. doi: http://dx.doi.org/10.1590/0034-7167-2018-0561

\section{Corresponding Author:}

Fernanda Penido Matozinhos E-mail: nandapenido@hotmail.com

\section{ABSTRACT}

Objective: to evaluate the association of Obstetric Nursing in the best practices of delivery and birth care in maternity hospitals. Method: a cross-sectional study, with 666 women selected for delivery. Parturition obstetric practices performed by professionals were categorized into: clearly useful practices that should be encouraged, practices that are clearly harmful or ineffective and that should be eliminated and practices used inappropriately at the time of parturition. Results: clearly useful practices were used in greater proportions in the hospitals that had Obstetric Nursing working, while clearly harmful practices and those used inappropriately were practiced in smaller proportions in hospitals that had Obstetric Nursing, both with statistical difference. Conclusion: institutions with Obstetric Nursing adopt better practices of delivery and birth care, based on scientific evidence, when compared to those that do not act.

Descriptors: Obstetric Nursing; Labor, Obstetrics; Parturition; Humanized Delivery; Obstetrics; Birth.

\section{RESUMO}

Objetivo: avaliar a associação da Enfermagem Obstétrica nas boas práticas da assistência ao parto e nascimento em maternidades. Método: estudo transversal, com 666 mulheres selecionadas por ocasião da realização de parto. As práticas obstétricas realizadas pelos profissionais que assistiam o processo de parturição foram categorizadas em: práticas claramente úteis e que devem ser estimuladas, práticas claramente prejudiciais ou ineficazes e que devem ser eliminadas e práticas usadas de modo inapropriado no momento de parturição. Resultados: práticas claramente úteis foram utilizadas em maiores proporções nos hospitais que possuíam a Enfermagem Obstétrica atuante, enquanto práticas claramente prejudiciais e aquelas usadas de modo inapropriado foram praticadas em menores proporções em hospitais que possuíam a Enfermagem Obstétrica, ambas com diferença estatística. Conclusão: instituiç̃ões com Enfermagem Obstétrica adotam melhores práticas de atenção ao parto e nascimento, baseadas em evidências científicas, quando comparadas às que ela não atua. Descritores: Enfermagem Obstétrica; Trabalho de Parto; Parto; Parto Humanizado; Obstetrícia; Nascimento.

\section{RESUMEN}

Objetivo: evaluar la asociación de la Enfermería Obstétrica en las buenas prácticas de la asistencia al parto y el nacimiento en maternidades. Método: estudio transversal, con 666 mujeres seleccionadas con ocasión de la realización del parto. Las prácticas obstétricas realizadas por los profesionales que asistían al proceso de parturición se clasificaron en: prácticas claramente útiles y que deben ser estimuladas, prácticas claramente perjudiciales o ineficaces y que deben ser eliminadas y prácticas utilizadas de modo inapropiado en el parto. Resultados: las prácticas claramente útiles fueron utilizadas en mayores proporciones en los hospitales que poseían la Enfermería Obstétrica actuante, mientras prácticas claramente perjudiciales y aquellas usadas de modo inapropiado fueron practicadas en menores proporciones en hospitales que poseían la Enfermería Obstétrica, ambas con diferencia estadística. Conclusión: las instituciones con Enfermería Obstétrica adoptan mejores prácticas de atención al parto y nacimiento, basadas en evidencias científicas, cuando comparadas a las que no actúa.

Descriptores: Enfermería Obstétrica; Trabajo de Parto; Parto; Parto Humanizado; Obstetricia; Nacimiento. 


\section{INTRODUCTION}

Delivery and birth forms the life cycle of many women, and for many years it has been a personal and private event shared with other women, their relatives and midwives. These, considered reliable people for the pregnant women or with recognized experience in the community, performed delivery care from the popular knowledge and experience constructed within their communities ${ }^{(1)}$.

Over time, the scientific transformations in the ways of life have consolidated values that favor the strong technologies, the economic benefit, and the biological science influenced in a significant way the care provided to women during birth. The technocratic care model based on the body's conception as a machine for women as an object and of delivery as a dangerous event was consolidated, replacing the popular care provided to women ${ }^{(2)}$.

The technocratic model implied the institutionalization of delivery and birth in hospitals, consolidating a set of standardized obstetric practices, with the primacy of technology over human relations ${ }^{(3)}$.Such interventionist practices have made the obstetric context often a setting of violence and, when performed without scientific criteria or indication, may increase the risk of post-delivery complications ${ }^{(4)}$. These culminated in a situation called "Perinatal Paradox", which describes the maintenance of high rates of maternal and perinatal morbidity and mortality, related to poor quality of care and use of obsolete and iatrogenic practices ${ }^{(5)}$.

Reflections of abusive interventions have crossed the centuries and, currently, Brazil's position as one of the countries with the highest cesarean rates represents, clearly, this process of medicalization. In view of the increasing rate of cesarean delivery in Brazil since the 1980 s, it is possible to characterize labor (LA) and delivery care as excessively interventionist and consider it one of the main complication points in delivery. In 2016, cesarean accounted for $88 \%$ of birth certificates in private services and $46 \%$ in the Brazilian Unified Health System (SUS - Sistema Único de Saúde), reaching an average rate of $52 \%{ }^{(6)}$. This rate is much higher than the $15 \%$ ceiling recommended by the World Health Organization (WHO) ${ }^{(7)}$.

The risk of complications intrinsic to this alarming number of cesareans, especially those performed without indication, contributes to the increase in maternal mortality rates. Evidence shows that cesareans, even though they are elective, they are also associated with a higher prevalence of post-delivery antibiotic use and an increase in preterm births ${ }^{(8)}$. Moreover, causalities of high rates of cesarean sections represent a significant additional expense for health systems that are already overburdened and often weakened ${ }^{(9)}$.

From the 1980s, the understanding of irrational use of these technologies, as pointed out by international social movements and health institutions, guided the construction of new policies in which the insertion of Obstetric Nursing was thought as a power for the transformation of the delivery care model. Obstetric Nursing in hospital institutions, in fact, represented a redirection to a woman-centered model of care, in its protagonism and autonomy, as well as in obstetric practice based on scientific evidence ${ }^{(3,10)}$.

In this context, WHO has issued recommendations on patterns of treatment and care related to pregnant women in order to reduce unnecessary interventions. These practices were subsequently ratified by the Ministry of Health $(\mathrm{MoH})$ and are known as best practices in care for vaginal delivery. They are based on scientific evidence and are one of the most important milestones in the transition to the Brazilian obstetric care model(3).

Best practices of care for vaginal delivery were classified in order to guide the professional's behavior: clearly useful practices that should be encouraged; Practices that are clearly harmful or ineffective and should be eliminated; and inappropriately used practices at the time of LA and delivery. In Brazil, best practices during LA occurred in less than $50 \%$ of women in 2014, with worse rates for the North, Northeast and Center-West regions ${ }^{(11)}$.

Recent publications from $\mathrm{WHO}^{(12)}$ and $\mathrm{MoH}^{(13)}$, in order to synthesize available scientific information on delivery and birth care, confirm the concern of these organs with the global obstetric setting. Despite efforts and incentives to use best practice, unnecessary interventions are still very frequent and, as a consequence, maternal mortality rates remain high ${ }^{(14)}$. In Brazil, in 2012, 1,552 maternal deaths were recorded per 100,000 live births, and in the Southeast the rate was found in 540 maternal deaths per 100,000 live births. In Minas Gerais, 111 maternal deaths per 100,000 live births were recorded ${ }^{(15)}$.

Delivery care, therefore, must be safe and linked to the scientific evidence, in order to encourage the autonomy of women and give a new meaning to this unique moment of parturition for women and professionals who live it ${ }^{(16)}$. There are few nursing studies about best practices for vaginal delivery associated with the presence of Obstetric Nursing and the hospital care model. This work may therefore indicate ways to improve the model of obstetric care in the city of Belo Horizonte, based on the reflection on the subjects who participate in these practices, as well as practices during $L A$, delivery, and birth.

\section{OBJECTIVE}

To evaluate the association of Obstetric Nursing in best practices of delivery and birth care in public and private maternity hospitals in the city of Belo Horizonte.

\section{METHOD}

\section{Ethical aspects}

This study was approved by the Research Ethics Committee of the Universidade Federal de Minas Gerais and by the Ethics Committees of the maternity hospitals involved. The collection of data was initiated after the parturients' signature was obtained through the Free and Informed Consent Form.

\section{Design, place of study and period}

It is an observational study with a cross-sectional design, developed with research data:"Birth in Belo Horizonte - National Enquiry into Labour and Birth", carried out in 7 maternities that meet the public health network and in 4 maternity hospitals that meet the supplementary health network of Belo Horizonte - Minas Gerais.

The survey "Birth in Belo Horizonte - National Inquiry into Labor and Birth" used the same method of sampling, logistics and material resources of the Brazilian study entitled "Birth in Brazil- National Enquiry into Labour and Birth“(17-18). 


\section{Sample}

In this study, 666 women admitted to maternity units selected for delivery and who started LA (induced or not), regardless of the birth route.

The data collection took place from November 2011 to March 2013 , through an interview with puerperae, at least 6 hours after delivery. This time was pre-established as the minimum interval defined for post-delivery rest and by means of investigation in their medical records. This step was performed with the aid of a standardized questionnaire with sociodemographic identification variables, clinical history, as well as other variables.

\section{Study protocol}

The obstetric practices performed by the professionals who assisted LA and delivery were created following recommendations from $\mathrm{WHO}^{(19)}$ and $\mathrm{MoH}^{(6)}$ and were organized into three categories for the purpose of this study: clearly useful practices which should be encouraged (offering of diet, freedom of movement and movement, presence of companion, use of partograph and non-pharmacological methods (NPM) for pain relief); practices which are clearly harmful or ineffective and which should be (enema, tricotomy, "lying on the back with legs raised" position at the time of Kristeller's delivery and maneuver); and practices used inappropriately at the time of LA and delivery (amniotomy, oxytocin infusion, analgesia, and episiotomy) ${ }^{(3)}$.

For this study, the exhibition counted on three categories following the delivery care models prevalent in the institutions: presence of Obstetric Nursing working in direct care for LA; presence of Obstetric Nursing in the institution (but not directly acting in the work of LA); and hospitals without the presence of Obstetric Nursing.

\section{Analysis of results and statistics}

For the analysis of the data, the statistical package Statistical Software for Professional (Stata), version 14.0 was used.

The population description of this study was performed and the estimates were presented in proportions (\%), with their respective Confidence Intervals $(95 \% \mathrm{Cl})$. For the quantitative variables, after asymmetry was verified by the Shapiro-Wilk Test, data were presented by means of median and interquartile range (IQ).

In order to verify the difference in the proportions between obstetric practices performed by professionals serving LA and delivery, and different delivery care models, the Pearson's Chi-Square Test or Fisher's Exact Test. In the variables presenting a statistical difference, a Bonferroni correction analysis was performed in order to avoid type I errors derived from multiple comparisons. The analyzes were performed and stratified according to the final birth route. A significance level of $5 \%$ was considered in all analytical procedures.

It should be emphasized that the sample number of the variables may be different in certain categories resulting from the LA evolution.

\section{RESULTS}

The median age of the sample of the 666 women in this study was 26 years $(\mathrm{IQ}=21-31$ years), with a predominance of self-reported brown color (68.17\%), women not engaged in paid work $(53.30 \%$ had high school (59.05\%) and had a stable union (66.97\%) (Table 1).

Table 1 - Sample profile, Belo Horizonte, Minas Gerais, Brazil, 2011 - 2013

\begin{tabular}{lcc}
\hline & $\mathbf{n}(\%)$ & $\mathbf{9 5 \%} \mathbf{C l}$ \\
\hline Age* $^{*}$ & $26(21-31)$ & \\
Color & & \\
$\quad$ White & $1503(22.52)$ & $19.50-25.86$ \\
$\quad$ Black & $62(9.31)$ & $7.32-11.77$ \\
$\quad$ Brown* & $454(68.17)$ & $64.52-71.60$ \\
Paid occupation & & \\
$\quad$ Yes & $311(46.70)$ & $42.92-50.50$ \\
$\quad$ No & $355(53.30)$ & $49.49-57.07$ \\
Schooling level & & \\
$\quad$ None and Elementary School & $219(32.93)$ & $29.45-36.60$ \\
$\quad$ High School & $386(58.05)$ & $54.24-61.75$ \\
$\quad$ Higher Education & $60(9.02)$ & $7.06-11.45$ \\
Marital status & & \\
$\quad$ Stable union & & \\
$\quad$ Without partner & $446(66.97)$ & $63.29-70.44$ \\
& $220(33.03)$ & $29.55-36.70$ \\
\hline
\end{tabular}

Note: *Median (Interquartile Interval); *Include: Mulatto, brunette, yellow, and indigenous.

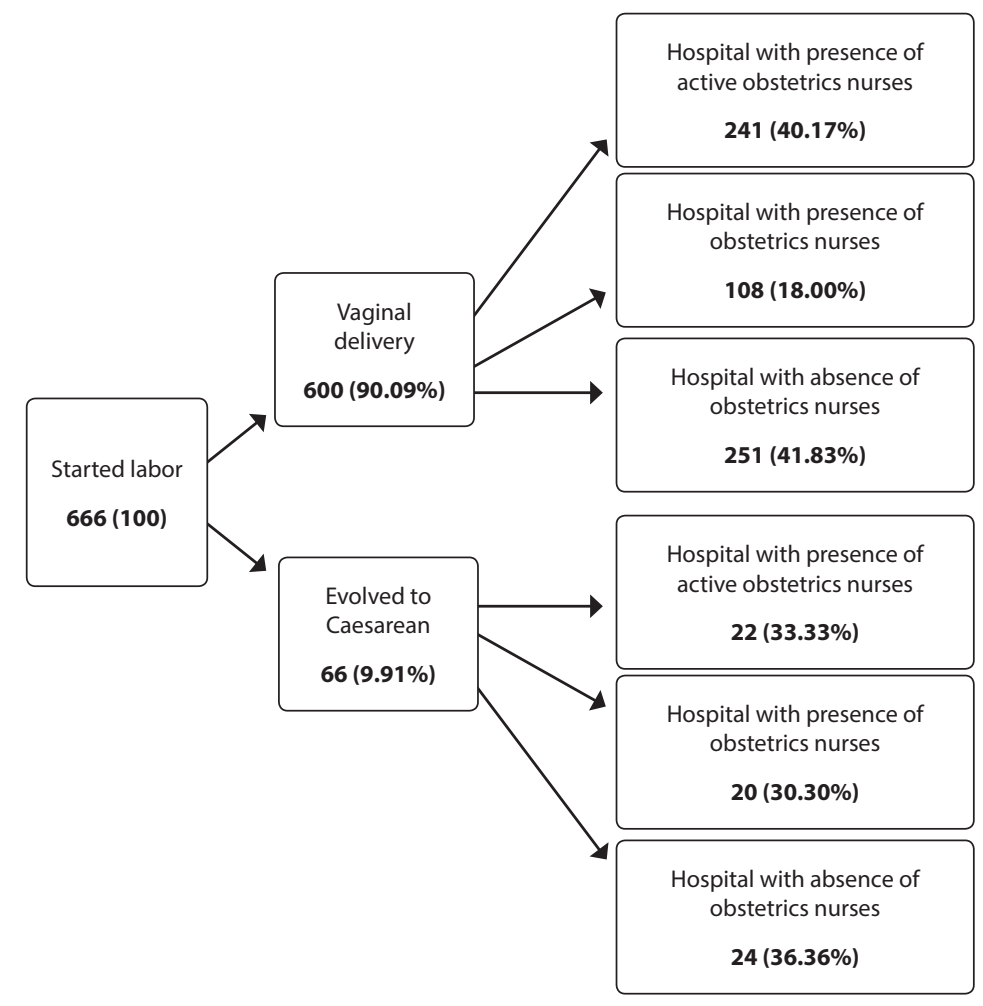

Note: LA - Labor; ON-Obstetric Nursing; Pearson's Chi-Square Test $=0.054$.

Figure 1 - Birth route and obstetric care model of the hospital at the time of delivery, Belo Horizonte, Brazil, 2011 to 2013

Figure 1 shows the distribution of the LA outcomes in relation to the birth pathway and the obstetric model present in hospital institutions. Of the 666 women who started LA, 66 (9.91\%) 
progressed to cesarean section, of which: 22 (33.33\%) were in hospitals where Obstetric Nursing was active, 20 (30.30\%) in hospitals that had presence of Obstetric Nursing (but without direct action in LA and delivery) and 24 (36.36\%) were in a hospital with absence of Obstetric Nursing. No statistical difference was observed in the groups in relation to the birth pathway, however, p value is at the critical level, demonstrating that, with the sample increase, there could be a statistical difference.

Obstetric practices during LA and delivery in women who progressed to the vaginal birth route can be observed in Table 2 . Regarding the clearly useful practices that should be encouraged, the highest proportions of women for whom diet was offered during $L A$, freedom of movement and position were encouraged. Partograph and NPM were used to relieve pain during LA, and were located in hospitals that had Obstetric Nursing, with a statistical difference in all variables (Table 2 ).

Table 2 shows, in relation to the practices that are clearly harmful or ineffective and that should be eliminated, smaller proportions for the practices of enema and tricotomy in the hospitals that had Obstetric Nursing, in relation to the hospitals that did not have this professional, with statistical difference. Regarding the practice of keeping the pregnant woman in a position "lying on the back with legs raised", the presence of Obstetric Nursing in the hospital was associated with lower proportions, statistically significant.

Table 2 - Obstetric practices during labor and delivery in relation to Obstetric Nursing for women who had their children through the vaginal route, Belo Horizonte, Minas Gerais, Brazil 2011 to 2013

\begin{tabular}{|c|c|c|c|c|}
\hline & \multicolumn{3}{|c|}{ Hospital with presence of obstetrics nurse } & \multirow{2}{*}{$p$ value } \\
\hline & Active & Presence & No & \\
\hline \multicolumn{5}{|c|}{ Practices that are clearly useful and should be encouraged } \\
\hline $\begin{array}{l}\text { Diet offer } \\
\text { No } \\
\text { Yes }\end{array}$ & $\begin{array}{c}\text { A } \\
106(26.84) \\
123(68.33)\end{array}$ & $\begin{array}{c}\text { B } \\
83(21.01) \\
19(10.56)\end{array}$ & $\begin{array}{c}\text { B } \\
206(52.15) \\
38(21.11)\end{array}$ & $<0.001$ \\
\hline $\begin{array}{l}\text { Freedom of movement and position } \\
\text { No } \\
\text { Yes }\end{array}$ & $\begin{array}{c}\text { A } \\
9(10.11) \\
184(52.12)\end{array}$ & $\begin{array}{c}\text { B } \\
16(17.98) \\
60(17.00)\end{array}$ & $\begin{array}{c}C \\
64(71.91) \\
109(30.88)\end{array}$ & $<0.001$ \\
\hline $\begin{array}{l}\text { Accompanying person } \\
\text { No } \\
\text { Yes }\end{array}$ & $\begin{array}{c}11(55.00) \\
230(39.66)\end{array}$ & $\begin{array}{c}2(10.00) \\
106(18.28)\end{array}$ & $\begin{array}{c}7(35.00) \\
244(42.07)\end{array}$ & 0.409 \\
\hline $\begin{array}{l}\text { Partograph } \\
\text { No } \\
\text { Yes }\end{array}$ & $\begin{array}{c}A \\
53(25.85) \\
181(49.45)\end{array}$ & $\begin{array}{c}\text { B } \\
53(25.85) \\
55(15.03)\end{array}$ & $\begin{array}{c}\mathrm{B} \\
99(48.29) \\
130(35.52)\end{array}$ & $<0.001$ \\
\hline $\begin{array}{l}\text { NPM for pain relief } \\
\text { No } \\
\text { Yes }\end{array}$ & $\begin{array}{c}\text { A } \\
57(22.89) \\
173(52.58)\end{array}$ & $\begin{array}{c}\text { B } \\
50(20.08) \\
54(16.41)\end{array}$ & $\begin{array}{c}\text { B } \\
142(57.03) \\
102(31.00)\end{array}$ & $<0.001$ \\
\hline \multicolumn{5}{|c|}{ Practices that are clearly harmful or ineffective and should be eliminated } \\
\hline $\begin{array}{l}\text { Enema } \\
\text { No } \\
\text { Yes }\end{array}$ & $\begin{array}{c}\text { A } \\
234(41.34) \\
0\end{array}$ & $\begin{array}{c}A B \\
108(19.08) \\
0\end{array}$ & $\begin{array}{c}\text { B } \\
224(39.58) \\
5(100)\end{array}$ & 0.015 \\
\hline $\begin{array}{l}\text { Tricotomy } \\
\text { No } \\
\text { Yes }\end{array}$ & $\begin{array}{c}\text { A } \\
234(41.34) \\
0\end{array}$ & $\begin{array}{c}A B \\
108(19.08) \\
0\end{array}$ & $\begin{array}{c}\text { B } \\
224(39.58) \\
5(100)\end{array}$ & 0.015 \\
\hline $\begin{array}{l}\text { "lying on the back with legs raised" position } \\
\text { No } \\
\text { Yes }\end{array}$ & $\begin{array}{c}\text { A } \\
72(83.72) \\
166(33.27)\end{array}$ & $\begin{array}{c}\text { B } \\
5(5.81) \\
99(19.84)\end{array}$ & $\begin{array}{c}\text { B } \\
9(10.47) \\
234(46.89)\end{array}$ & $<0.001$ \\
\hline $\begin{array}{l}\text { Kristeller Maneuver } \\
\text { No } \\
\text { Yes }\end{array}$ & $\begin{array}{c}237(41.43) \\
0\end{array}$ & $\begin{array}{c}108(18.88) \\
0\end{array}$ & $\begin{array}{c}227(39.69) \\
3(100)\end{array}$ & 0.156 \\
\hline \multicolumn{5}{|c|}{ Practices inappropriately used at the time of LA and delivery } \\
\hline $\begin{array}{l}\text { Amniotomy } \\
\text { No } \\
\text { Yes }\end{array}$ & $\begin{array}{c}123(50.00) \\
45(38.14)\end{array}$ & $\begin{array}{l}40(16.26) \\
26(22.03)\end{array}$ & $\begin{array}{l}83(33.74) \\
47(39.83)\end{array}$ & 0.090 \\
\hline $\begin{array}{l}\text { Oxytocin infusion } \\
\text { No } \\
\text { Yes }\end{array}$ & $\begin{array}{c}\text { A } \\
135(46.71) \\
99(35.11)\end{array}$ & $\begin{array}{c}B \\
40(13.84) \\
68(24.11)\end{array}$ & $\begin{array}{c}\text { A } \\
114(39.45) \\
115(40.78)\end{array}$ & 0.002 \\
\hline $\begin{array}{l}\text { Analgesia } \\
\text { No } \\
\text { Yes }\end{array}$ & $\begin{array}{c}A \\
202(49.03) \\
32(20.13)\end{array}$ & $\begin{array}{c}\mathrm{A} \\
86(20.87) \\
22(13.84)\end{array}$ & $\begin{array}{c}C \\
124(30.10) \\
105(66.04)\end{array}$ & $<0.001$ \\
\hline $\begin{array}{c}\text { Episiotomy } \\
\text { No } \\
\text { Yes }\end{array}$ & $\begin{array}{c}A \\
217(51.30) \\
20(13.16)\end{array}$ & $\begin{array}{c}\text { B } \\
57(13.48) \\
51(33.55)\end{array}$ & $\begin{array}{c}C \\
149(35.22) \\
81(53.29)\end{array}$ & $<0.001$ \\
\hline
\end{tabular}

Note: $p<0.05$ in bold, Fisher's Exact Test or Pearson's Chi-Square; NPM - Non-Pharmacological Methods; LA-Labor; similar letters mean similarity between the proportions of the group. 
Table 3 - Obstetric practices during labor and delivery in relation to Obstetric Nursing for women who had their children by cesarean section, Belo Horizonte, Minas Gerais, Brazil, 2011 to 2013

\begin{tabular}{|c|c|c|c|c|c|}
\hline & \multicolumn{3}{|c|}{ Hospital with presence of obstetrics nurse } & & \multirow{2}{*}{$p$ value } \\
\hline & Active & Presence & No & & \\
\hline \multicolumn{6}{|c|}{ Practices that are clearly useful and should be encouraged } \\
\hline Diet offer & A & $A B$ & & B & 0.032 \\
\hline No & $8(25.00)$ & $11(34.38)$ & $13(40.63)$ & & \\
\hline Yes & $11(57.89)$ & $6(31.58)$ & $2(10.53)$ & & \\
\hline Freedom of movement and position & & & & & 0.289 \\
\hline No & $2(20.00)$ & $4(40.00)$ & $4(40.00)$ & & \\
\hline Yes & $16(44.44)$ & $12(33.33)$ & $8(22.22)$ & & \\
\hline Accompanying person & & & & & 0.315 \\
\hline No & $2(50.00)$ & $2(50.00)$ & 0 & & \\
\hline Yes & $20(32.26)$ & $18(29.03)$ & $24(38.71)$ & & \\
\hline Partograph & & & & & 1.000 \\
\hline No & $3(50.00)$ & $2(33.33)$ & $1(16.67)$ & & \\
\hline Yes & $5(45.45)$ & $3(27.27)$ & $3(27.27)$ & & \\
\hline NPM for pain relief & A & A & & B & 0.012 \\
\hline No & $6(28.57)$ & $4(19.05)$ & $11(52.38)$ & & \\
\hline Yes & $13(43.33)$ & $13(43.33)$ & $4(13.33)$ & & \\
\hline \multicolumn{6}{|c|}{ Practices inappropriately used at the time of LA and delivery } \\
\hline Amniotomy & & & & & 0.545 \\
\hline No & $2(22.22)$ & $3(33.33)$ & $4(44.44)$ & & \\
\hline Yes & $1(33.33)$ & $2(66.67)$ & 0 & & \\
\hline Oxytocin infusion & & & & & 0.574 \\
\hline No & $1(11.11)$ & $3(33.33)$ & $1(11.11)$ & & \\
\hline Yes & $3(37.50)$ & $2(25.00)$ & $3(37.50)$ & & \\
\hline Analgesia & & & & & 0.683 \\
\hline No & $5(50.00)$ & $2(20.00)$ & $3(30.00)$ & & \\
\hline Yes & $3(42.86)$ & $3(42.86)$ & $1(14.29)$ & & \\
\hline
\end{tabular}

Note: $p<0.05$ in bold, Fisher's Exact Test or Pearson's Chi-Square; NPM - Non-Pharmacological Methods; LA - Labor; similar letters mean similarity between the proportions of the group..

In the practices used inappropriately at the time of LA and delivery, there was Obstetric Nursing in the hospital associated with lower proportions of oxytocin infusion and analgesia use, with a statistically significant difference. In hospitals where Obstetric Nursing was active, there were higher proportions of non-episiotomy compared to the other hospitals with different models of obstetric care, statistically significant (Table 2).

Regarding the obstetric practices during LA and delivery in women who progressed to cesarean section, it was observed for the clearly useful and encouraging practices, greater proportions of diet offering and NPM use for pain relief for women who were in LA in the institutions where the presence of Obstetric Nursing was present, with statistical difference between the groups (Table 3 ).

\section{DISCUSSION}

This study demonstrated that the presence of Obstetric Nursing substantially reduces the rates of interventions performed and that, possibly, their presence is directly related to higher rates of vaginal deliveries. A recent study showed that the presence of Obstetric Nursing in LA care and delivery in maternity hospitals has a positive impact, including the reduction of cesarean sections ${ }^{(20)}$. The process of performing the delivery offered by Obstetric Nursing is centered on the promotion of practices based on scientific evidence seeking to rescue the protagonism of women in the process of giving birth ${ }^{(21)}$.

Regarding obstetric practices in women who received vaginal delivery, it was observed that "Practices that are clearly useful and should be encouraged" were used in greater proportions in the hospitals that had Obstetric Nursing working. In contrast, "Practices that are clearly harmful or ineffective and should be eliminated" and "inappropriately used practices" were practiced to a lesser extent in hospitals that had Obstetric Nursing. Regarding obstetric practices, in women who progressed to cesarean section in hospitals with active Obstetric Nursing, clearly useful practices were also used in greater proportions. It can be inferred, therefore, that the active presence of Obstetric Nursing at the time of LA and delivery characterizes a more humanized and less interventionist care, emphasizing the safety and well-being of women at parturition ${ }^{(22)}$.

Implanted fasting by professionals may cause unsatisfactory progression of LA leading to unnecessary interventions and possibly resulting in a cesarean section ${ }^{(23)}$. In parturition, energy expenditure is the equivalent of continuous moderate physical exercise. Therefore, the supply of fluids and foodstuffs orally to the parturient, respecting their desire, besides not interfering in the development of LA and delivery can be beneficial ${ }^{(24)}$.

Regarding the freedom of movement and position, in this study it was observed greater proportions in the presence of Obstetric Nursing. The findings resemble recent studies ${ }^{(3,20-21)}$.

The movement of the parturient during LA increases maternal comfort and facilitates the progression of $L A^{(11)}$, besides reducing $L A$ time and not being associated with the increase of interventions or negative effects on the well-being of mothers and babies ${ }^{(25)}$. Ambulance in the 1st stage of LA and change of position contribute to an effective relief of contraction pain 
and lower rates of cesarean section or use of forceps, as well as reduction of perineal trauma and less blood loss during $L A^{(26)}$.

Regarding the completion of the partograph, this study evidenced that the presence of Obstetric Nursing is associated with greater proportions of the use of this tool. The main objective of the partograph is to provide an overview of LA, to alert the professional about deviations in maternal or fetal well-being and progress in $L A^{(27)}$, besides contributing to an efficient exchange of information among the multiprofessional team ${ }^{(28)}$.

Regarding NPMs for pain relief, this study observed greater proportions in its use, when Obstetric Nursing was active in the institution. A representative study of the Brazilian population showed that onethird of the women received NPM during LA (31.3\%), with greater acceptance in women whose deliveries were served by Obstetric Nursing, and twice as likely to be offered in their presence. NPM reduce parturient stress and anxiety levels and promote greater satisfaction ${ }^{(29)}$. It is important to emphasize and value the autonomy of women in LA, since each one faces this phase differently ${ }^{(30)}$.

It is important to emphasize the importance of the companion in the delivery and birth process, a study carried out in southern Brazil, showing that the support of the companion is associated with best practices and movement, able to reduce the pain and duration of $L A^{(31)}$.

Regarding harmful or ineffective delivery care practices, they are still routinely used in many health institutions in Brazil ${ }^{(32)}$. In this study, in the presence of Obstetric Nursing working in the institution, there were lower proportions for use of enema, trichotomy, and "lying on the back with legs raised" position.

Regarding the routine use of enema, the presence of Obstetric Nursing working in the institution was associated with its nonachievement, when compared to institutions that do not have this professional. The use of enemas in women admitted to LA does not have a significant effect on infection rates, besides there is dissatisfaction on the part of women about this practice and therefore it should be discouraged ${ }^{(33)}$.

The presence of Obstetric Nursing in the institution was associated with non-performance of trichotomy when compared to institutions that did not have Obstetric Nursing. In 2014, a systematic review demonstrated that there is insufficient evidence to recommend perineal tricotomy for women on admission to $\mathrm{LA}^{(34)}$, since it does not influence better rates of infection, dehiscence of the perineal wound or other neonatal infections ${ }^{(31)}$.

"lying on the back with legs raised" position was observed in smaller proportions when Obstetric Nursing was active in the institution, being more common in the institution where there was no Obstetric Nursing. The use of this practice should be discouraged for practitioners and civil society. Nevertheless, it is known that this position is culturally accepted as the ideal for delivery by women and health professionals ${ }^{(3)}$. Scientific evidence shows that the delivery of upright positions and ambulation in the $1^{\text {st }}$ phase of labor reduce LA time and the need for analgesia. Therefore, the act of verticalizing the woman contributed to increase the oxygenation of the fetus during the expulsive period and also increase the pelvic diameters when squatting or kneeling ${ }^{(35)}$.

Regarding the practices used inappropriately in LA and delivery, the use of analgesia and episiotomy were associated with lower proportions when Obstetric Nursing was present in the institution (in relation to the institution that did not have Obstetric Nursing in its staff). Nonetheless, oxytocin infusion has been shown to be associated with lower proportions when Obstetric Nursing was present, but not active, in the institution - when compared to other care models. It is emphasized that the non-association when the birth route was cesarean derives from the fact that such practices are used in a more advanced period of LA.

A study had already demonstrated that the presence of Obstetric Nursing did not interfere in oxytocin infusion rates ${ }^{(20)}$. This practice, in addition to disrupting the natural course of delivery and freedom of movement of the parturient, is related to a more painful experience in LA and can culminate in an iatrogenic cesarean section - when used indiscriminately ${ }^{(21)}$.

Regarding analgesia, there are lower proportions of pregnant women who received this method of pain relief in the active presence of Obstetric Nursing in the institution - in relation to the institution that did not have it. In this study, there was no separation between the various types of analgesia available in the service. Nevertheless, the literature shows that pregnant women who use epidural analgesia as a form of pain relief are at greater risk of having an instrumental delivery ${ }^{(36)}$. It should also be emphasized that the institutions where Obstetric Nursing was active, adopt a less selective model of analgesia followed by information about the advantages and disadvantages of this procedure. This may have contributed to the decrease in the demand for analgesia in institutions where Obstetric Nursing was active ${ }^{(3)}$.

Of the practices used inappropriately at the time of LA and delivery, episiotomy is one of the procedures that causes more puerperal problems ${ }^{(37)}$. The $\mathrm{WHO}$ and $\mathrm{MoH}$ discourage the practice of episiotomy and is recommended in a maximum of $15 \%$ of cases - because it is a harmful practice in routine use ${ }^{(38)}$.

\section{Study limitations}

Some limitations in this study should be recognized. Firstly, it is a cross-sectional study, which makes it impossible to identify the temporality of the associations shown in the results. In this respect, the loss of some data is added, intrinsic to the fact that the data collection was also performed in medical records. However, sensitivity analyzes were carried out, noting that this aspect would not be significantly affecting the estimates, at least as regards the general conclusions.

\section{Contributions to Nursing}

Despite these limitations, this work advances in the perspective of analysis of data not yet fully explored on women's health. The results provide important epidemiological information, emphasizing that in institutions with Obstetric Nursing, even when not active in LA and delivery care, there are better perspectives when compared to institutions where it does not act.

\section{CONCLUSION}

It is observed that the introduction of Obstetric Nursing in hospitals increases the use of clearly useful practices, reducing the use of practices that are clearly harmful and inappropriately used when 
compared to institutions where Obstetric Nursing does not act. It is evident, therefore, the importance of Obstetric Nursing in the rescue of the physiology of the act of giving birth, in addition to the technologies related to the humanization of care delivery, enhancing the voice of the woman in the process of delivery and birth and appropriating the obstetric practice based on scientific evidence.

Participation of obstetrics nurses in the delivery and birth care, in part of the institutions studied, demonstrates the confidence of the managers in the teamwork, or collaborative work, for the safety of humanized care. At the same time, it proposes that because of the difficulty of insertion of these professionals in Brazilian health institutions, their presence in the parturient care process already shows evidence that there is an interest of these institutions, specifically in the transformation of the care model based on evidence scientific.
Therefore, it is the responsibility of health professionals, especially Obstetric Nursing, who is identified in this study as a strategic agent in changing the care model, favoring and encouraging the role of women, for decision-making based on $\mathrm{WHO}$ and $\mathrm{MoH}$ recommendations. Moreover, ethical conduct and effective communication among all professionals involved in delivery care and women and their families are essential actions that contribute to the comprehensiveness of care. They can positively imply the sense of control of this process and the experience of this particular event.

\section{FUNDING}

This study was financed by the National Council for Scientific and Technological Development (Conselho Nacional de Desenvolvimento Científico e Tecnológico-CNPq).

\section{REFERENCES}

1. Progianti JM, Barreira IA. A obstetrícia, do saber feminino a medicalização: da época medieval ao século XX. Rev Enferm UERJ. 2001;9(1):91-7

2. Davis-Floyd R. Ways of knowing about birth: mothers, midwives, medicine, and birth activism. Long Grove: Waveland Press; 2017.

3. Sousa AMM, Souza KV, Rezende EM, Martins EF, Campos D, Lansky S. Practices in childbirth care in maternity with inclusion of obstetric nurses in Belo Horizonte, Minas Gerais. Esc Anna Nery. 2016;20(2):324-31. doi: 10.5935/1414-8145.20160044

4. Vogt SE, Silva KS, Dias MAB. Comparison of childbirth care models in public hospitals, Brazil. Rev Saúde Pública. 2014;48(2):1-10. doi: 10.1590/S0034-8910.2014048004633

5. Lansky S, Friche AAL, Silva AAM, Campos D, Bittencourt SDA, Carvalho ML, et al. Birth in Brazil survey: neonatal mortality, pregnancy and childbirth quality of care. Cad Saúde Pública. 2014;30(Suppl 1):S1-S15. doi: 10.1590/0102-311X00133213

6. Leal MC, (Coord.). Nascer no Brasil: Sumário Executivo Temático da Pesquisa. [Internet]. Rio de Janeiro: Fundação Oswaldo Cruz; 2016 [cited 2018 Nov 12]. Available from: http://www.ensp.fiocruz.br/portal-ensp/informe/site/arquivos/anexos/nascerweb.pdf

7. Lago TDG, Lima LP. Assistência à gestação, ao parto e ao puerpério: diferenciais regionais e desigualdades socioeconômicas. In: Ministério da Saúde (BR). Centro Brasileiro de Análise e Planejamento (CEBRAP). Pesquisa Nacional de Demografia e Saúde da Criança e da Mulher - PNDS 2006 [Internet]. Brasília: Ministério da Saúde, CEBRAP; 2009 [cited 2018 Nov 12]. p. 151-68. Available from: http://bvsms.saude.gov.br/bvs/publicacoes/ pnds_crianca_mulher.pdf

8. Victora CG, Aquino EML, Leal MC, Monteiro CA, Barros FC, Szwarcwald CL. Maternal and child health in Brazil: progress and challenges. Lancet. 2011;377(9780):1863-76. doi: 10.1016/S0140-6736(11)60138-4

9. World Health Organization (WHO). Declaração da OMS sobre Taxas de Cesáreas [Internet]. Geneva: WHO; 2015 [cited 2018 Nov 12]. Available from: https://apps.who.int/iris/bitstream/handle/10665/161442/WHO_RHR_15.02_por.pdf;jsessionid=622BF93D5287165CC6526C 910235A661? sequence $=3$

10. Davis-Floyd R. The technocratic, humanistic and holistic paradigms of childbirth. Int J Gynaecol Obstet. 2001; 75(1):S5-23. doi: 10.1016/ S0020-7292(01)00510-0

11. Leal MC, Pereira APE, Domingues RMSM, Theme Filha MM, Dias MAB, Nakamura-Pereira $M$ et al. Obstetric interventions during labor and childbirth in Brazilian low-risk women. Cad Saúde Pública. 2014; 30(Suppl 1):S1-31. doi: 10.1590/0102-311X00151513

12. World Health Organization (WHO). Intrapartum care for a positive childbirth experience [Internet]. Geneva: WHO; 2018 [cited 2018 Nov 12]. Available from: https://www.who.int/reproductivehealth/publications/intrapartum-care-guidelines/en/

13. Ministério da Saúde (BR). Diretrizes nacionais de assistência ao parto normal [Internet]. Brasília: Ministério da Saúde; 2017 [cited 2018 Nov 12]. Available from: http://bvsms.saude.gov.br/bvs/publicacoes/diretrizes_nacionais_assistencia_parto_normal.pdf

14. Carvalho EMP, Göttems LBD, Pires MRGM. Adherence to best care practices in normal birth: construction and validation of an instrument. Rev Esc Enferm USP. 2015;49(6):889-97. doi: 10.1590/S0080-623420150000600003

15. Ferraz L, Bordingnon M. Mortalidade materna no Brasil: uma realidade que precisa melhorar. Rev Baiana Saúde Pública. 2012;36(2):527-38. doi: 10.22278/2318-2660.2012.v36.n2.a474

16. Silva LR, Christoffel, MM, Souza KV. História, conquistas e perspectivas no cuidado à mulher e à criança. Texto Contexto Enferm. 2005;14(4):585-93. doi: 10.1590/S0104-07072005000400016

17. Vasconcellos MTL, Silva PL, Pereira APE, Schilithz AOC, Souza Jr PRB, Szwarcwald CL. Sampling design for the Birth in Brazil: National Survey into Labor and Birth. Cad Saúde Pública. 2014;30(Supl. S1-S10):S49-58. doi: 10.1590/0102-311X00176013 
18. Leal MC, Silva AAM, Dias MAB, Gama SGN, Rattner D, Moreira ME et al. Birth in Brazil: national survey into labour and birth. Reprod Health. 2012;9:15. doi: 10.1186/1742-4755-9-15

19. World Health Organization. Care in Normal Birth: A Practical Guide Technical. Appropr Technol. 1997;24(2):121-3. doi: 10.1111/j.1523536X.1997.00121.pp.x

20. Gama SGN, Viellas EF, Torres JA, Bastos MH, Brüggemann OM, Theme Filha MM, et al. Labor and birth care by nurse with midwifery skills in Brazil. Reprod Health. 2016;13(Suppl 3):123. doi: 10.1186/s12978-016-0236-7

21. Reis TR, Zamberlan C, Quadros JS, Grasel JT, Moro ASS. Obstetric Nurses: contributions to the objectives of the Millennium Development Goals. Ver Gaúcha Enferm. 2015;36(esp):94-101. doi: 10.1590/1983-1447.2015.esp.57393

22. Narchi NZ, Cruz EF, Gonçalves R. The role of midwives and nurse-midwives in promoting safe motherhood in Brazil. Ciênc Saúde Colet. 2013;18(4):1059-68. doi: 10.1590/S1413-81232013000400019

23. Wei CY, Gualda DMR, Santos Jr HPO. Movimentação e dieta durante o trabalho de parto: a percepção de um grupo de puerpéras. Texto Contexto Enferm. 2011;20(4):717-25. doi: 10.1590/S0104-07072011000400010

24. Amorim T, Gualda DMR. Práticas comprovadamente úteis e que devem ser estimuladas durante o trabalho de parto e parto, que estão sendo realizadas por enfermeiras obstétricas: revisão da literatura. RECENF. 2010;25(8):152-9.

25. Lawrence A, Lewis L, Hofmeyr GJ, Dowswell T, Styles C. Maternal positions and mobility during first stage labour. Sao Paulo Med. J. 2001;129(5):361-2. doi: 10.1590/S1516-31802011000500015

26. Leite DMS. Efeitos da deambulação e das posições verticais na evolução do primeiro período de trabalho de parto na mulher primípara [dissertação] [Internet]. Porto: Escola Superior de Enfermagem do Porto; 2014 [cited 2018 Jun 30]. Available from: http://hdl.handle. net/10400.26/9527

27. Lavender T, Hart A, Smyth RM. Effect of partogram use on outcomes for women in spontaneous labour at term. Cochrane Database Syst Rev. 2013;(7):CD005461. doi: 10.1002/14651858.CD005461.pub4

28. Aguiar CA. Práticas obstétricas e a questão das cesarianas intraparto na rede pública de saúde São Paulo [Dissertação]. São Paulo: Universidade de São Paulo; 2012. doi: 10.11606/D.6.2012.tde-15032012-104625

29. Gayeski ME, Bruggemann OM. Non-pharmacological approach to pain relief during labor as hard-light care technology: a systematic review. Texto Contexto Enferm. 2010;19(4):774-82. doi: 10.1590/S014-07072010000400022

30. Mafetoni RR, Shimo AKK. Non-pharmacological methods for pain relief during labor: integrative review. REME - Rev Min Enferm. 2014;18(2):513-20. doi: 10.5935/1415-2762.20140037

31. Monguilhott JJC, Brüggemann OM, Freitas PF, d'Orsi E. Nascer no Brasil: the presence of a companion favors the use of best practices in delivery care in the South region of Brazil. Rev Saúde Pública. 2018;52:1. doi: 10.11606/s1518-8787.2018052006258

32. Santos JO, Shimo AKK. Prática rotineira da episiotomia refletindo a desigualdade de poder entre profissionais de saúde e mulheres. Esc Anna Nery. 2008;12(4):645-50. doi: 10.1590/S1414-81452008000400006

33. Reveiz L, Gaitán HG, Cuervo LG. Enemas during labour. Cochrane Database Syst Rev. 2013;(7):CD000330. doi: 10.1002/14651858.CD000330.pub4

34. Basevi V, Lavender T. Routine perineal shaving on admission in labour. Cochrane Database Syst Rev. 2014;(11):CD001236. doi: 10.1002/14651858.CD001236.pub2

35. Lehugeur D, Strapasson MR, Fronza E. Non-pharmacological management of relief in deliveries assisted by an obstetric nurse. J Nurs UFPE On Line. 2017;11(12):4929-37. doi: 10.5205/1981-8963-v11i12a22487p4929-4928-2017

36. Anim-Somuah M, Smyth R, Howell C. Epidural versus non-epidural or no analgesia in labour. Cochrane Database Syst Rev. 2011;(12):CD000331. doi: 10.1002/14651858.CD000331.pub3

37. Viana IO, Quintão A, Andrade CRA, Ferreira FA, Dumont RD, Ferraz FO, et al. Episiotomia e suas complicações: revisão da literatura. Rev Med Minas Gerais [Internet]. 2011 [cited 2018 Jun 30];21(2 Supl. 4):S1-113. Available from: http://rmmg.org/artigo/detalhes/893

38. Guimarães NNA, Silva LSR, Matos DP, Douberin CA. Analysis of factors associated with the practice of episiotomy. Rev Enferm UFPE. 2018;12(4):1046-53. doi: 10.5205/1981-8963-v12i4a231010p1046-1053-2018 